\title{
EVALUATION OF HAMSTRING FLEXIBILITY BY USING TWO DIFFERENT MEASURING INSTRUMENTS
}

\author{
Bakirtzoglou Panteleimon $^{1}$, Ioannou Panagiotis ${ }^{2} \&$ Bakirtzoglou Fotis $^{3}$ \\ ${ }^{1}$ Organisation for Vocational Education and Training in Greece, Athens, Greece \\ ${ }^{2}$ Faculty of Physical Education and Sports Science, Thessaloniki, Greece \\ ${ }^{3}$ General Hospital of Thessaloniki "Agios Dimitrios", Thesaloniki, Greece
}

\begin{tabular}{|c|c|c|}
\hline DOI: 10.5550 /sgia. 1002028 & COBISS.BH-ID 1846808 & $\begin{array}{r}\text { SHORT SCIENTIFIC ARTICLE } \\
\text { UDC: } 616.728 .3: 796.012 .23\end{array}$ \\
\hline
\end{tabular}

\section{SUMMARY}

The purpose of the present study was to investigate the effect of two different methods of measurement for hamstring flexibility. Forty male students athletes with mean age $23.45 \pm 0.44$ years and forty non-athletes students with a mean age $23.08 \pm 0.98$ years participated in this study. Hamstring flexibility was evaluated by two different methods of measurement: a) a Myrin goniometer and b) sit and reach test. Statistical analysis included the use of Independent Samples Ttest while significance was set at $\mathrm{p}<0.01$. The results indicated that athletes students scored better than non-athletes students only when hip joint's mobility was measured with a Myrin goniometer. In conclusion the evaluation of joint's mobility should be done by using a method of measurement that would isolate the articulation of measurement from the interjection of other joints or muscular teams something that is achieved by the use of Myrin goniometer than the use of Sit and Reach test.

Key words: hamstrings, Myrin goniometer, sit and reach test.

\section{INTRODUCTION}

Sports performance is the result of the interplay of various mental and physical factors. One of the main factors to improve and maximize athletic performance is the development of physical abilities. The capabilities of fitness are strength, speed, endurance and flexibility (American College of Sports Medicine, 1995).

Flexibility has been defined in many ways. It is used the term joint mobility indicates the degree of bending the normal range or scope of a joint or series of joints (Moller \& Oberg, 1984).

Several sit-and-reach tests (SRs) are commonly used in health-related and physicalfitness test batteries to evaluate the hamstring and lower back flexibility (Jackson \& Baker,
1986; Hoeger et al, 1990; Hui and Yuen, 2000). Such field measures are only moderate indicators of hamstring extensibility. However, the SRs are frequently used to evaluate the hamstring muscle extensibility because the procedures are simple, easy to administer, require minimal skills training and are particularly useful in large scale extensibility evaluation in the field setting. The classical SR (Wells \& Dillon, 1952) was originally selected as a part of the American Alliance for Health, Physical Education, Recreation \& Dance (AAHPERD) health-related and physical- fitness protocol, and is often included in standard fitness tests (e.g., EUROFIT: personal fitness tests, President's Challenge) and health related fitness programs (Institute for Aerobic Research, 1988) and A.A.H.P.E.R.D. (AAHPERD, 1984). 
During measuring joint's mobility, however, a joint should be used as instruments to limit interference with other muscle groups or joints in the final measurement result. According to Harris (1969), the joint must be isolated at the time of measurement. Myrin goniometer isolates the joint from the interference of other joints without affecting the final outcome of measuring the length of other muscle groups (Leighton, 1955). Unlike measurement with the Sit and Reach test may lead to different results, because in anatomy and motion analysis of the test, participating in the final outcome of the measurement back muscles, hamstrings and the triceps surae muscle complex (Kendall et al, 1971). Most research has not dealt with the issue of the effect of the measure instrument to the final result of the measurement of a joint mobility.

The purpose of the present study was to examine whether the use of two different instruments for the evaluation of knee joint's mobility may affect the final result of measurement between untrained and trained individuals.

\section{METHOD}

\section{Participants}

Forty student-athletes and forty students (non athletes) participated in this study. Student-athletes had an average age of $23.45 \pm$ 0.44 years, height $1.89 \pm 0.69 \mathrm{~cm}$ and weight $84.56 \pm 12.43 \mathrm{~kg}$. The relevant anthropometric characteristic of students (non-athletes) was: age, years $23.08 \pm 0.98$, height $1.86 \pm 0.97 \mathrm{~cm}$ and weight $91 \pm 13.46 \mathrm{~kg}$. Both studentathletes and students (non-athletes) do not have a musculoskeletal problem before the time of measurement.

\section{Procedure}

Testing took place in the exercise room at a private gym. Before testing, all participants performed a three minute warm up and static stretch routine, emphasizing the lower body. Immediately after the stretching, the flexibility tests were performed in a counterbalanced design. All tests were assessed on the same day for each student. The participants were allowed to rest for 20 minutes between tests. One physiotherapist was responsible for each test. All measures were performed on the same day, and all tests were conducted with the participants wearing their shoes. For the evaluation of knee joint's mobility have been used two different instruments: the Myrin goniometer (Leighton, 1955) and Sit and Reach test (Wells \& Dillon, 1952). The measurement of hip flexion with knee straight with Myrin goniometer was tested in a medical bed. The initial and final position of each movement passively measured starting from the anatomical neutral point $\mathrm{O}$, as determined by the American Academy of Orthopedic Surgeons (1965). Testing room temperature was kept at $25^{\circ} \mathrm{C}$.

\section{Measures}

\section{Goniometric Measurement}

The Myrin goniometer (Lic Rehab. 17183 Solna, Sweden) is a goniometer vertical and horizontal measurements based on Leighton flexometer (1955). It consists of a circular range (0-180th) degrees turntable and two indices. One indicator is mounted in the center of the disc controlled by gravity for vertical measurements and the other is an indicator of orientation for horizontal measurements. The measurement was performed using American Academy of Orthopedic Surgeons (1965) procedures. A manual goniometer was used to measure flexibility as the range of motion in the hip joint and related musculature, while the participant lay supine on a firm, level examining table. The examiner raised the tested leg slowly and evenly, with the knee fully extended, avoiding abduction and rotation, until tightness or pain restricted the movement. The upward motion of the straight leg was measured to the nearest degree from the zero starting position. The hamstring flexibility score was determined as the mean of two measurements of the left and right legs. Ekstrand et al. (1982) demonstrated the reliability of measuring joint range of motion as a measure of hamstring flexibility. 


\section{Sit and Reach Test}

The Sit and Reach test is a wooden device with the following dimensions: length of base $35 \mathrm{~cm}$, width $45 \mathrm{~cm}$, height $32 \mathrm{~cm}$ and length $55 \mathrm{~cm}$. To standardize the measurement scale of Sit and Reach, a standard meter rule was placed on the sit-and-reach box for each test, with the reading of $23 \mathrm{~cm}$ in line with the heel position of each test. The participants sat on the floor with shoes on, and fully extended two legs so that the sole of the foot was flat against the end of the box. They extended their arms forward, placing one hand on top of the other. With palms down, they reached forward sling hands along the measuring scale as far as possible without bending the knee of the extended leg. Throughout testing, the physiotherapist checked to ensure that the heel remained at the $23 \mathrm{~cm}$ mark. Three trials were performed on one side. Then the participant changed leg position and repeated the procedure on the other side. The average of the three trials on each side was used for subsequent analyses. Reaches short of the toes were recorded as negative forward reach scores, and reaches beyond the toes were recorded as positive forward reach scores. The forward reach scores were recorded in centimeters to the nearest $0.5 \mathrm{~cm}$ using the scale on the box (AAHPERD, 1984).

\section{Statistical analysis}

For the statistical analysis the statistical package SPSS for windows (Statistical Package for the Social Sciences, Chicago, IL) was used. Descriptive statistics including means and standard deviations were calculated for all the variables. Independent Samples T-test was used to find statistically significant differences between untrained and trained students to assess the flexibility of the knee by the use of two different measuring methods. Significance level was set at $\mathrm{p}<0.01$.

\section{RESULTS}

The anthropometric characteristics of student-athletes and students (non-athletes) are listed in Table 1. There were statistically significant differences between groups in weight $(p<0.01)$.

TABLE 1.

Anthropometric characteristics of students (non-atbletes) and students (atbletes). The values are averages \pm standard deviation.

\begin{tabular}{lcc}
\hline & Students(non-athletes) & Student-athletes \\
\hline Age (years) & $23.45 \pm 0.44$ & $23.08 \pm 0.98$ \\
\hline Height $(\mathrm{cm})$ & $1.89 \pm 0.69$ & $1.86 \pm 0.97$ \\
\hline Weight $(\mathrm{cm})$ & $84.56 \pm 12.43$ & $\mathbf{9 1 . 0 0 \pm 1 3 . 4 6}$ \\
\hline $\mathrm{p}<.01$ &
\end{tabular}

The performance of student-athletes and the untrained students using the instrumentation of the Myrin goniometer and Sit and reach test appear in Table 2. There were statistically significant differences between the two groups when using the Myrin goniometer for the evaluation of knee joint's mobility ( $p$ $<0.01)$.

\section{DISCUSSION}

This study was designed with the assumption that the instrument plays a key role in evaluating the mobility of a joint or a muscle group. Sit and reach test is commonly used in health-related and physical-fitness test batteries to evaluate the hamstring and lower back flexibility (Wells and Dillon, 1952; Jackson and Baker, 1986; Jackson and Langford, 1989; Hoeger et al, 1990; Liemohn et al 1994, Simoneau, 1998) and others included the Myrin goniometer (Chung and Yuen, 1999; Hui and Yuen, 2000; Baltaci et al, 2003).

Myrin goniometer (LIC rehab, 17183 Solna, Sweden)) is often used to determine hamstring flexibility by executing a maximum, 
passive straight-leg raise on each leg, (Ekstrand, Wiktorsson, Oberg, \& Gillquist, 1982; Jackson \& Baker, 1986; Jackson \& Langford, 1989; Minkler \& Patterson, 1994).

However, comparing these two instruments Kendall et al (1971) report that Sit and Reach test does not isolate the joint at the time of measurement and the final result would probably be due to physiological or limited length of the muscles of the knee, back and triceps surae muscle complex. Unlike the Myrin goniometer isolate the joint measurement, so the final result of measurement is the length of the extensor muscles (Moller \& Oberg, 1984; Kippers \& Parker, 1987).

Most research has not dealt with the issue of the effect of the measure instrument to the final result of the measurement of a joint mobility. In this study used two different instruments in order to determine whether the use of two different instruments for evaluation hamstring flexibility will affect the final result of measurement.

TABLE 2.

Performance of student (non-athletes) and students-athletes in the evaluation of hamstring flexibility with the Myrin goniometer and the Sit and Reach test. The values are averages \pm standard deviation.

\begin{tabular}{lcc}
\hline & Students(non-athletes) & Students-athletes \\
\hline Goniometer Myrin $(\mathrm{o})$ & $82.00 \pm 3.14$ & $\mathbf{8 8 . 0 0 \pm 2 . 2 6}$ \\
\hline Sit and reach test $(\mathrm{cm})$ & $21.98 \pm 2.17$ & $22.40 \pm 1.18$ \\
\hline $\mathrm{p}<.01$ & &
\end{tabular}

\section{CONCLUSION}

Significant differences were only observed by the use of the Myrin goniometer for the evaluation of hamstring flexibility, in relation to Sit and Reach test, because it isolates the joint. In this study, knees joint mobility of trained and untrained individuals evaluated by the same score when used as a measure instrument the Sit and Reach test but this is likely due to the interference of other muscle groups in the measurement result. In contrast, trained student had higher results in the measurement of knees joint mobility from untrained student when using the Myrin goniometer, because the goniometer isolates the joint measurement, and the final result due
In this study, both students-athletes and students (non-athletes) had no statistically significant differences when used as an instrument for hamstring flexibility the Sit and Reach test. These results did not support the findings of Jackson and Baker (1986) and Chung and Yuen (1999) indicating that athletes have better statistical performance than non-athlete. Using the Sit and Reach test except for knee joint, back muscles and triceps surae muscle complex are involved (Kendall et al, 1971). Therefore the same performance between the two groups may be due to the physiological or limited length of back muscles, knee and triceps surae muscle complex.

Rather, when used as measuring instrument the Myrin goniometer differences between the two groups was statistically significant in favor of student-athletes. This result is in agreement with Kendall et al (1971) and Jackson \& Langford (1989) indicating that athletes perform better than untrained subjects in evaluation of flexibility with the Myrin goniometer. to the length of the extensor muscles without involving other muscle groups or joints.

\section{REFERENCE:}

A.A.H.P.E.R.D. (1984). Technical manual for the bealth related physical fitness test. Washington, DC: Author.

American Academy of Orthopedic Surgeons. (1965). Joint Motion: Method of measuring and recording. Chicago, IL: Park Ridge

American College of Sports Medicine. (1995). Guidelines for exercise testing and prescription. Philadelphia: Lea and Febiger.

Baltaci, G.N.UN, Tunay, V.A., Besler, S. \& Gerceker, S. (2003). Comparison of three 
different sit and reach tests for measurement of hamstring flexibility in female university students. Br. J. Sports Med. 37(1), pp. 59-61.

Chung, P.K. \& Yuen, C.K. (1999). Criterionrelated validity of sit-and-reach tests in university men in Hong Kong: Perceptual and Motor Skills. 88(1), pp. 304-316.

Ekstrand, J., Wiktorsson, M., Oberg, B, \& Gillquist, J. (1982). Lower extremity goniometric measurements: A study to determine their reliability. Arch. Phys. Med. Rebabil. 63(4), pp. 171-175.

Harris, M.L. (1969). A factor analytic study of flexibility. Res. Q. Exerc. Sport. 40, pp. 62-70.

Hoeger, W.W.K., Hopkins, D.R., Button, S. \& Palmer, T.A. (1990). Comparing the sit and reach with the modified sit and reach in measuring flexibility in adolescents. Pediatric Exercise Science 2, pp. 156-162.

Hui, S.S.C. \& Yuen, P.Y. (2000). Validity of the modified back-saver sit-and-reach test: a comparison with others protocols. Med. Sci. Sports Exerc. 32(9), pp. 1655-1659.

Institute for Aerobics Research (1988). The Fitnessgram. Dallas: Author.

Jackson, A.W. \& Baker, A.A. (1986). The relationship of the sit and reach test to criterion measures of hamstring and back flexibility in young females. Res. Q. Exerc. Sport. 57, pp. 183-186.

Jackson, A.W. \& Langford, N.J. (1989). The criterion-related validity of the sit and reach test: Replication and extension of previous findings. Res. Q. Exerc. Sport. 60(4), pp. 384387.

Kendall, H.O., Kendall, F.P. \& Wadsworth, G.E. (1971). Muscles: Testing and Function. (2nd ed.). Baltimore. MD: Williams and Wilkins.

Kippers, V. \& Parker, A.W. (1987). Toe touch test. A measure of its validity. Physical Therapy, 67(11), pp. 1680-84.

Leighton, J.R. (1955). Instrument and technique for measurement of range of joint motion. Archives Physical Medicine Rehabilitation, 36, pp. 571-78.

Liemohn, W., Sharpe, G.L. \& Wasserman, J.F. (1994). Criterion related validity of the sitand- reach test. J. Strength Cond Res. 8(2), pp. 91-94.

Minkler, S. \& Patterson, P. (1994). The validity of the modified sit-and-reach test in college-age students. Research Quarterly for Exercise and Sport 65, pp. 189-192.

Moller, B. \& Oberg, B. (1984). Athletic training and flexibility. A study on range of motion in the lower extremity. Thesis, Linkoping.

Simoneau, G.G. (1998). The impact of various anthropometric and flexibility measurements on the Sit-and-Reach test. J. Strength Cond Res. 12(4), pp. 232-237.

Wells, K.F. \& Dillon, E.K. (1952). The sit and reach: A test of back and leg flexibility. Res. Q. for Exerc. Sport. 23, pp. 115-118.

Received: October, $20^{\text {th }} 2010$

Accepted: December, $13^{\text {th }} 2010$

Correspodence to:

Panteleimon Bakirtzoglou Ph.D

Organisation for Vocational Education and Training

Ethikis Antistaseos 41 - OEEK

TK.142 34

Athens-Nea Ionia

Phone: +306975909631

E-mail: bakirtzoglou@gmail.com 


\title{
PROCJENA FLEKSIBILNOSTI KOLJENA KORIŠĆENJEM DVA RAZLLCITTA MJERNA INSTRUMENTA
}

\author{
Bakirtzoglou Panteleimon ${ }^{1}$, Ioannou Panagiotis ${ }^{2} \&$ Bakirtzoglou Fotis $^{3}$ \\ ${ }^{1}$ Organizacija za stručno obrazovanje i obuku u Grčkoj, Atina, Grčka \\ ${ }^{2}$ Fakultet fizičkog obrazovanja i sportskih nauka, Solun, Grčka \\ ${ }^{3}$ Solunska opšta bolnica"Agios Dimitrios", Solun, Grčka
}

Razvoj fizičkih sposobnosti (snage, brzine, izdržljivosti i fleksibilnosti - American College of Sports Medicine, 1995) je jedan od glavnih preduslova za unapređenja i povećanja sportskih postignuća. Nekoliko sjedi-i-dohvati testova (SRs), za procjenu fleksibilnosti koljena i donjeg dijela leđa, se redovno koristi u baterijama testova koje su vezani za zdravlje i fizičku aktivnost. (Jackson \& Baker, 1986; Hoeger et al, 1990; Hui and Yuen, 2000). Izvođenje ovih testova je jednostavno, lako za evidentiranje rezultata, zahtijeva minimalne sposobnosti koje su razvijene treningom i posebno je primjenljivo za procijenu fleksibilnosti u ovom prostoru. Klasični SR (Wells \& Dillon, 1952), kao prvi konstruisani test, često je bio uključivan u fitnes programe vezane za zdravlje (A.A.H.P.E.R.D., 1984; Institute for Aerobic Research, 1988). Prilikom mjerenja pokretljivosti zgloba važno je da se ograniči uticaj drugih mišićnih grupa ili zglobova na konačan rezultat mjerenja. Prema Harrisu (1969), zglob mora da bude izolovan za vrijeme mjerenja. Upotrebom Myrin goniometra zglob se izoluje od drugih zglobova i uticaja drugih mišićnih grupa na finalni rezultat. (Leighton, 1955) Za razliku od prethodnog testa, sjedi-i-dohvati test može da pokaže drugačije rezultate. Anatomska i biomehanička analizi pokazuju da na konačan rezultat ovog testa imaju uticaj mišići leđa, koljena i triceps surae. (Kendall et al, 1971)

Cilj ovog rada bio je da se ispita da li se upotrebom dva različita instrumenta za procjenu pokretljivosti zgloba koljena može uticati na konačan rezultat merenja treniranih i netreniranih osoba.

Četrdeset studenata (sportista) i četrdeset studenata (nesportista) učestvovali su u ispitivanju. Prosječna starost studenata (sportista) je 23,45 $\pm 0,44$ godine, visina $1,89 \pm 0,69 \mathrm{~cm} \quad i$ težina $84,56 \pm 12,43 \mathrm{~kg}$. Antropometrijske karakteristike studenata (nesportista) su: visina $1,86 \pm 0,97 \mathrm{~cm}$ i težina $91,00 \pm 13,46 \mathrm{~kg}$; a njihova starost bila je $23,08 \pm 0,98$ godina. Studenti (sportisti) kao i studenti (nesportisti) nisu imali nikakvih mišićno-skeletnih problema prije mjerenja.

Testiranje je izvedeno u sali za vježbanje. Sva mjerenja su izvršena istog dana, i svi su testovi sprovedeni tako što su ispitanici bili u patikama. Učesnici su mogli da se odmore 20 minuta izmedu testova. Jedna osoba (fizioterapeut) sprovodio je oba testa. Za procjenu pokretljivosti zgloba koljena korišćena su dva različita mjerna instrumenta: Myrin goniometar (Leighton, 1955) i sjedi-idohvati test (Wells \& Dillon, 1952).

$\mathrm{Za}$ statističku analizu korišćen je SPSS statistički paket za Windows. Deskriptivna statistika, uključujući srednje vrijednosti i standardnu devijaciju, izračunate su za sve varijable. Za pronalaženje statistički značajnih razlika u procjeni fleksibilnosti koljena, sa dvije različite metode mjerenja, između treniranih i netreniranih studenata, korišćen je T-test nezavisnih uzoraka. Traženi nivo značajnosti je $\mathrm{p}<0,01$.

Ustanovljena je statistički značajna razlika između ove dvije grupe kada se koristio Myrin goniometar za procjenu fleksibilnosti zgloba koljena $(\mathrm{p}<0,01)$. Nije pronađena statistički značajna razlika između treniranih i netreniranih ispitanika prilikom korišćenja sjedi-i-dohvati testa.

$\mathrm{U}$ ovom istraživanju primjenjena su dva različita instrumenta da bi se utvrdilo da li postoje razlike u rezultatima mjerenja prilikom njihovog upotrebe. Poredeći ova dva instrumenta Kendall et al (1971) konstatuje da 
sjedi-i-dohvati test ne izoluje zlob tokom mjerenja i da konačan rezultat vjerovatno zavisiti od ograničenja uslovljenih dužinom mišića leđa, koljena i triceps surae. Za razliku od toga Myrin goniometar izoluje zglob, tako da na konačan rezultat mjerenja utiče samo dužina mišića ekstenzora (Moller \& Oberg, 1984; Kippers \& Parker, 1987). U ovom istraživanju i studenti (sportisti) i student (nesportisti) nisu pokazali statistički značajnu razliku kada je kao instrument za procenu fleksibilnosti koljena korišćen sjedi-i-dohvati test. Ovi rezultati nisu potvrdili zaključke Jackson i Baker (1896) niti Chung i Yuen (1999) koji su pokazali da sportisti, statistički gledano, imaju bolje rezultate od nesportista. Koristeći sjedi-i-dohvati test, osim zgloba koljena, u pokret su takođe uključeni mišići leđa i triceps surae (Kendall et al, 1971). Stoga, razlika u mjerenju između dvije grupe je uslovljena uticajem mišića leđa, koljena i triceps surae na mjerenje. Drugim riječima, kada je korišćen Myrin goniometar razlike između dvije grupe su bile statistički značajne u korist studenata sportista. Ovaj rezultat je u saglasnosti sa Kendall et al (1971) i Jackson \& Langford (1989) koji pokazuje da sportisti imaju bolje rezultate od netreniranih prilikom procjene fleksibilnosti sa Myrin goniometrom.

Značajne razlike primjećene su samo pri korišćenju Myrin goniometra, u odnosu na sjedi-i-dohvati test. Razlog tome je što prvi test izoluje zglob. U ovom istraživanju fleksibilnost koljenog zgloba treniranih i netreniranih osoba procijenjena je sa potpuno istim rezultatom kada je kao merni instrument korišten sjedi-i-dohvati test, a uzrok tome je uticaj drugih mišićnih grupa na rezultate mjerenja.

Ključne riječi: koljena, Myrin goniometar, sjedi-i-dohvati test. 